\title{
Challenges in Predicting Risks of Premature Coronary Artery Disease (PCAD)
}

(Cabaran dalam Meramal Risiko Penyakit Arteri Koronari Pramatang (PCAD))

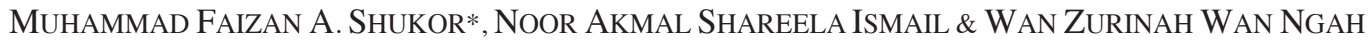

\begin{abstract}
Coronary artery disease $(C A D)$ predominantly manifests in older population above the age of 60 years old. The incidence of $C A D$ in younger individuals has been reported and is called premature CAD ( $P C A D)$. The prevalence for pCAD in individuals below 45 years old is about 3-10\% worldwide. Advances in risk prediction are of great importance as absolute values of risk factors sometimes correlate poorly with individuals. The measurement of traditional risk factors such as cholesterol level and blood pressure might be inadequate to predict risk for pCAD and therefore new biomarkers are required. The introduction of omics technology offers insight into the mechanism and interactions involved during disease progression and open the possibilities of discovering new biomarkers. Currently, new potential biomarkers for pCAD have been explored such as homocysteine, apolipoproteins, microRNAs and single nucleotide polymorphisms. In this review, we discussed the associated risk factors for pCAD, several reported and newly proposed biomarkers and their potential to be used clinically.
\end{abstract}

Keywords: Atherosclerosis; biomarker; premature coronary artery disease

\section{ABSTRAK}

Penyakit arteri koronari (CAD) sering berlaku dalam populasi yang berumur 60 tahun ke atas. Walau bagaimanapun, kejadian dalam individu muda yang dipanggil CAD pramatang ( $p C A D)$ telah dilaporkan. Prevalens pCAD bagi individu di bawah umur 45 tahun adalah 3-10\% di seluruh dunia. Kemajuan dalam meramal risiko adalah penting kerana nilai faktor risiko mutlak kadangkala berkorelasi lemah dengan individu. Pengukuran faktor risiko tradisi seperti paras kolesterol dan tekanan darah mungkin tidak mencukupi untuk meramal risiko pCAD, oleh itu penanda biologi baru diperlukan. Pengenalan teknologi omik memberikan lebih kefahaman terhadap mekanisme dan interaksi yang berlaku sewaktu perkembangan penyakit dan membuka kemungkinan untuk penemuan penanda biologi baru. Ketika ini, penanda biologi pCAD yang baru telah diteroka seperti homosisteina, apolipoprotein, mikroRNA dan polimorfisma nukleotida tunggal. Dalam ulasan ini, kami membincangkan tentang faktor risiko pCAD yang berkaitan, beberapa penanda biologi yang dilaporkan dan yang baru dicadangkan dan potensi mereka untuk digunakan secara klinikal.

Kata kunci: Aterosklerosis; penanda biologi; penyakit koronari arteri pramatang

\section{INTRODUCTION}

Coronary artery disease $(\mathrm{CAD})$ remains one of the leading causes of death in the world, despite a decrease in mortality and morbidity rates in the past decade (Nichols et al. 2014). CAD is commonly found among older individuals, while the prevalence among the younger population varies between 3 and 10\% (Mohan et al. 2001; Wilson et al. 1998). In America, the predisposition risk of cardiovascular disease in men between 30-34 years old is $3 \%$ and the risk increased to $21 \%$ when they reach 60-64 years old (Wilson et al. 1998). In Japan, the prevalence is 1.26 cases for every 1000 patients below 50 years old (Satoh et al. 2006) while in India, the prevalence recorded is about 10\% (Mohan et al. 2001). Another study reported that, only a small percentage $(<10 \%)$ of all patients with myocardial infarction are among individuals below 45 years old (Morillas et al. 2007). In Malaysia, $24 \%$ of 16,872 ACS patients that have been admitted to 17 hospitals in Malaysia between 2006 and 2010 were below 50 years old. $33 \%$ of them were active smokers, $33 \%$ were diagnosed with dyslipidemeia, $61 \%$ were hypertension, $41 \%$ were diabetic and $11 \%$ have family history with premature CAD (pCAD) (Wan Ahmad \& Sim 2013). Compared to other country databases, Malaysian who undergone percutaneous coronary intervention (PCI) were much younger and have higher prevalence for risk factors (Ahmad et al. 2013). Although most studies suggest a low incidence rate for PCAD, it is possible that the exact number of young individuals with atherosclerosis is probably much larger than currently estimated. In addition, the rise in cardiovascular risk factors such as smoking and obesity among younger population could lead to an increase in pCAD cases (Arzamendi et al. 2011). Therefore early detection and treatment of subclinical CAD and the prevention of developing acute coronary events should be emphasized among young adults.

Predicting risk and disease development is challenging and cardiovascular disease is no exception. Absolute values 
of risk factors such as cholesterol level sometimes correlate poorly within individuals (Castelli 1996). Accurately determining the risk among the younger population is paramount if prevention strategies were to be targeted appropriately. Current understanding on pathobiology of atherosclerosis has linked inflammation (Libby 2012) and oxidative stress (Madamanchi et al. 2005) as the central contributors to the initiation and progression of coronary artery disease. Identifying associated markers that may have prognostic values for future cardiovascular events in high risk patients may be crucial. Importantly, it will be useful in predicting diseases among individuals with no apparent syndrome or in younger populations who tend to develop CAD earlier in life. This could improve early diagnosis and enhance prevention strategies. In this review, we discussed on the associated risk factors, biomarkers as well as novel approaches that has been proposed in the literature focusing on pCAD.

\section{RISK FACTORS ASSOCIATED WITH PCAD}

A number of variables has been suggested to be predictive of cardiovascular events and such variables qualify as risk factors for CAD. Risk factors can be categorized into two different groups - modifiable and non-modifiable. Modifiable risk factors such as smoking, cholesterol levels, blood pressure and diabetes mellitus can be controlled by lifestyle interventions while non-modifiable risk factors such as age, gender and family history are factors that cannot be altered (Table 1).

TABLE 1. Associated risk factors for CAD and pCAD

\begin{tabular}{cc}
\hline \multicolumn{2}{c}{ CAD risk factors } \\
\hline Non-modifiable & Modifiable \\
\hline Age & Smoking status \\
Sex & Blood pressure \\
Race & Diabetes Mellitus \\
Family history & Cholesterol levels \\
& Physical activity \\
& Obesity \\
\hline
\end{tabular}

\section{GENDER}

It is well-acknowledged that pCAD is highly associated with males. Several studies have reported differences in baseline characteristics and clinical presentations between men and women. For instance, women with acute coronary syndrome (ACS) in the Canadian population are significantly older and are more likely to have diabetes, hypertension and a history of heart failure (Poon et al. 2012). Studies from PROSPECT, AMIS PLUS Registry and Gulf RACE-2 have recorded similar findings (Lansky et al. 2012; Radovanovic et al. 2007; Shehab et al. 2013). It was also reported that women were more frequently to have normal or mild disease when presented to angiogram (Dey et al. 2009). Although the incidence of acute myocardial infarction remains highest in men, women appeared to exhibit the worst prognosis (Milcent et al. 2007). Young women showed a greater post-infarction mortality in hospital and up to 1-year after discharge in comparison to men (4.23\% vs. 2.21\%, p = 0.005) (Egiziano et al. 2013). A study on gender related risk factors showed that women have significantly higher frequency of diabetes, family history of CAD and hypertension. In addition, women with a positive family history showed the greatest risk factor burden including traditional risk factors of hypertension $(67 \%)$, obesity $(53 \%)$, dyslipidemia $(67 \%)$, smoking $(42 \%)$ and diabetes $(33 \%)$ and non-traditional risk factors of depression (37\%), anxiety $(55 \%)$ and low household income (44\%) (Choi et al. 2014). While women have higher rates of hypertension and diabetes, their background were seen less among the smokers (Shehab et al. 2013). Although the prevalence for smoking among women is lower, it has been shown to give a greater effect on women with 60 percent increased risk for coronary heart disease (CHD) as compared to men who smoke (Prescott et al. 1998).

\section{FAMILY HISTORY WITH CAD}

Family history of CAD has been established as an independent risk factor for CAD from multiple populations based studies. It is estimated that heredity contributes to at least $50 \%$ of susceptibility to CAD. Importantly, the strength of risk is higher with younger age of onset (Sesso et al. 2001). In a survey of 15,381 patients, the frequency of young patients having family history of CAD $(43.6 \%)$ is significantly higher compared to late onset CAD (26.5\%) (Reibis et al. 2012) supporting the contribution of heredity to the occurrence of pCAD. A subsequent study from CONFIRM Registry involving 6308 young patients has reported that those with a family history of CAD have higher prevalence of pCAD. After a follow-up period, patients with family history of CAD also experienced higher annual rates of myocardial infarction (Otaki et al. 2013). A similar observation is recorded in Framingham Offspring Study as parental cardiovascular disease has been found to independently predict future events in middle age offspring. Among 2302 subjects (mean age $=44$ years), 164 men and 79 women had cardiovascular events during follow-up. Those who have at least one parent with pCAD had higher risk for events, with OR=2.6 (95\% CI, 1.7-4.1) for men and 2.3 (95\% CI, 1.3-4.3) for women after adjusted with age compared to control (Lloyd-Jones et al. 2004).

In asymptomatic first degree relative of patients with pCAD, the frequency of abnormal calcium scores is twofold higher compared to control with OR=1.96 (95\% CI 1.04 $-3.67, p<0.05)$ (Taraboanta et al. 2012). A non-premature parental coronary disease appears to be a weaker predictor (Lloyd-Jones et al. 2004). The risk frequency differs according to the population studied implying a genetic determinant or race-specific association for the disease. Multi ethnic comparison involving 13,591 patients from 3 ethnic groups (Malay, Chinese and Indian) in Malaysia 
revealed that the Indians have the highest frequency of family history of PCAD suggesting a strong genetic predisposition to CAD in this ethnic group ( $\mathrm{Lu} \&$ Nordin 2013). White middle age group with any parental history of premature CVD (pCVD) also appear to have higher odds of coronary artery calcium than those with no parental history $(\mathrm{OR}=1.55,95 \%$ CI 1.01-2.37). Significant association has also been observed between parental pCVD with intima media thickness in Caucasians with paternal pCVD (OR= $1.93,95 \%$ CI 1.10-3.39) or any parental pCVD (OR=1.67, $95 \%$ CI 1 .02-2.74) while no association has been observed in black participants (Wilkins et al. 2014).

\section{SMOKING}

Despite all efforts to reduce smoking on a global scale, smoking remains as one of the strongest risk factors for pCAD (Hbejan 2011; Hozawa et al. 2006). Previous research involving 200 patients below 35 years old who underwent coronary angiography reported that smoking (71\%) is the most frequent risk factor in pCAD (Christus et al. 2011). Furthermore, the attributable proportions of CHD among women who smoke in 8 pooled cohort studies were highest in the young group with $88 \%$ for $40-49$ years old, $81 \%$ for $50-59$ years old, $71 \%$ for $60-69$ years old and $68 \%$ for above 70 years old. The hazard ratio of CHD in current smokers relative to non-smokers also appears to be highest in the youngest and lowest in the oldest group in both men and women (Tolstrup et al. 2014). The relative risk for CAD for patients included in the Framingham Heart Study is about three times higher among young smokers as compared to the non-smokers. Pathobiological Determinants of Atherosclerosis in Youth (PDAY) reported that smokers $(32 \%)$ have over twice advanced lesions compared to the non-smokers (14\%) (Zieske et al. 1999). Smokers also have greater prevalence of Grade 5 lesions compared to the non-smokers suggesting that smoking accelerates the transition from Grade 4 to Grade 5 lesions (Zieske et al. 2005). Although smoking cessation in young healthy smokers showed normalization of endothelial dysfunction, smoking effect is not reversible in middle-age adults (Naya et al. 2011).

\section{CHRONIC DISEASES}

Diabetes, hypertension and hypercholesterolemia are also frequently present in early and late onset of CAD. These are considered as modifiable risk factors but involve both environmental as well as genetic components. Whereas the significant involvement of these factors in CAD progression is well documented, their importance amongst pCAD is still poorly described. Most studies on angiography profiles of $\mathrm{CAD}$ patients showed that older patients are more diabetic (Pineda et al. 2008; Uddin et al. 2004). However, the frequency of cardiovascular risk factors such as overweight and high cholesterol among young people with type 1 diabetes mellitus remained common (Dobrovolskienè et al. 2013). Similarly in Malaysia, the prevalence for hypertension was higher in people above 60 years old $(26.8 \%)$, while people between $40-49$ years old have the highest prevalence for obesity $(22.7 \%$ ) (Yunus et al. 2004). Young hypertensive subjects with multiple risk factors including positive family history $(\mathrm{OR}=12.317)$, low HDL $(\mathrm{OR}=3.267)$ and hypertriglyceridemia (OR= 2.894) are significantly associated with pCAD (Che et al. 2013). Although hypercholesterolemia is a common risk in $\mathrm{CAD}$, many researchers have reported a higher prevalence in younger group. The prevalence for this risk is about $73 \%$ in young patients compared to $59 \%$ in older patients (Pineda et al. 2008).

\section{PATHOGENESIS OF CAD}

The mechanism underlying the pathogenesis of CAD is the formation of atherosclerotic plaque characterized by deposition of cholesterol into the arterial wall. These events usually occur at the site of damaged endothelium possibly due to oxidative stress, physical forces or shear stress from the blood flow (Cunningham \& Gotlieb 2005). The pro-oxidant milieu in intima creates an oxidative stress environment and promotes LDL cholesterol oxidation. Oxidized LDL (oxLDL) can further damage endothelial cells and induce adhesion molecules expression such as P-selectin and trigger monocytes and leukocytes migration into the intima (Napoli et al. 1997). Endothelial cell, smooth muscle cells and macrophage then secretes growth factors and inflammatory cytokines (Ross 1993). In intima, monocytes differentiate into macrophage and internalize oxLDL via scavenger receptor SR-A and CD-36 (Kunjathoor et al. 2002). This process eventually leads to foam cells formation and stimulate smooth muscle cells to proliferate and form a cap on top of the plaque. In some cases, plaques become unstable due to degradation of collagen by matrix metalloproteinase (MMPs) and prone to rupture (Lin et al. 2014) resulting in formation of thrombus (Figure 1).

Atherosclerotic plaque development involves the interaction between many genes and the environment. Potential genes that attribute to the heritability component include several mutations that mostly affect HDL and LDL cholesterol levels such as LDLR, ApoB, ApoA1 and ABCA1 (Watkins \& Farrall 2006). Moreover, understanding the role of proteins that are important in inflammatory reaction such as VCAM-1, ICAM-1, IL-6 and MCP- 1 and regulatory process such as NF- $\chi \mathrm{B}$, TNF- $\alpha$ and IFN- $\gamma$, are essential as these genes and proteins have potential to become biomarkers for PCAD. Assessment of their function needs to be done carefully as some of them are capable of executing multiple actions (Ozaki \& Leonard 2002).

\section{POTENTIAL BIOMARKERS FOR PCAD}

Recently, the American College of Cardiology and the American Heart Association (ACC/AHA) has proposed a guideline for risk assessment for CAD (Goff et al. 2014). However, the recommendations did not emphasize on PCAD and only provide a rough estimation for individual risk. A number of studies also have proposed different types 


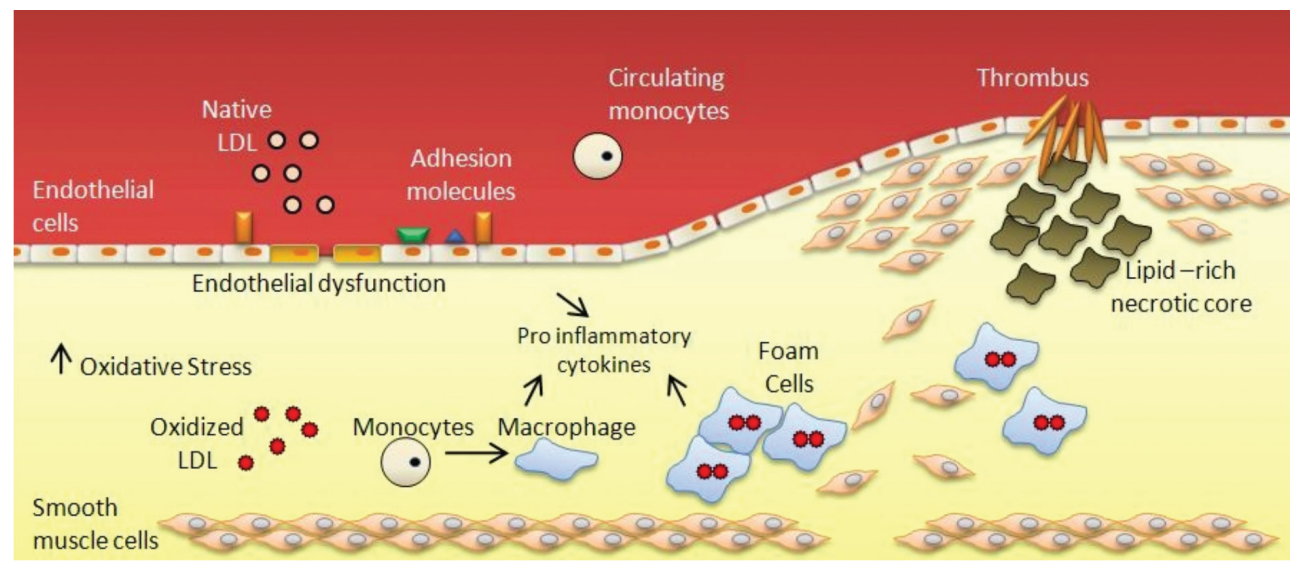

FIGURE 1. Mechanism of atherogenesis. Endothelial dysfunction promotes migration of LDL particle into the sub-endothelial space where they are subjected to oxidation by reactive oxygen species. Oxidized LDL further trigger endothelial cells to express adhesion molecules including VCAM-1 and ICAM-1 and promote monocytes migration. In the sub-endothelial space, macrophages internalize oxidized LDL and form foam cells. This process involves multiple components including pro-inflammatory cytokines such as IL-6 and TNF- $\alpha$ produced by endothelial cells, macrophages and foam cells. Pro-inflammatory cytokines induce smooth muscle cells migration and form a cap on top of the plaque. In some cases, the plaque become unstable and prone to rupture and leads to thrombus formation

of biomarkers for CAD (Siemelink \& Zeller 2014; Yayan 2013) while the importance of finding indicators for PCAD are fairly neglected. As some studies provide evidence that there are differences exist in the plaque morphology between younger and older CAD patients (Ruiz-Garcia et al. 2012), it is possible that current proposed biomarkers for CAD are not applicable for pCAD. Therefore there is an urgent need for studies that include risk assessment for young individuals and to develop biomarkers that are specific for this population.

\section{HOMOCYSTEINE}

An elevated serum concentration of homocysteine (a state called hyperhomocysteinemia) is a known risk factor for atherosclerosis and associated with an increased risk of myocardial infarction and mortality. An epidemiological study suggested a positive association between homocysteine (Hcy) concentrations and risk for cardiovascular disease (Graham et al. 1997). Previous data have shown that elevated homocysteine levels can be detected in $30 \%$ of CAD patients. The mechanisms involved by which homocysteine impairs vascular function is only partially understood. High homocysteine is involved in several potential mechanisms resulting in a decrease in the availability of endothelial cell-derived NO, impairment of endothelial function, an increment in monocyte adhesion (Faraci 2003), induction of oxidative stress, and increased tendency for thrombosis (Kaul et al.2006). Although most available data support the involvement of homocysteine in $\mathrm{CAD}$, most intervention studies which involved lowering homocysteine levels failed to reduce clinical events (Albert et al. 2008, Armitage et al. 2010).

The association of homocysteine with atherosclerosis in both case control observations and prospective cohort studies has been reported for pCAD. A case control study among male and female patients aged below 45 years with
CAD showed hyperhomocysteinemia as an independent risk factor for pCAD where the risk is higher in men (OR= 2.54,95\% CI, 1.23-5.22, $\mathrm{p}=0.01$ ). Hyperhomocysteinemia is shown to be significantly influenced by vitamin B12 deficiency (Sadeghian et al. 2006). A more recent study reported higher plasma homocysteine level in cases compared to healthy controls $(22.14 \pm 10.62 \mu \mathrm{mol} / \mathrm{l} \mathrm{vs}$ $17.38 \pm 8.46 \mu \mathrm{mol} / \mathrm{l})$ with $\mathrm{OR}=1.93(95 \% \mathrm{CI}, 1.27-2.94)$ (Gupta et al.2012). Homocysteine levels also appear to be higher in multiple vessel disease. The mean homocysteine levels are 12.6 and $15.5 \mu \mathrm{mol} / \mathrm{L}$ in patients with single and multi-vessel CAD respectively (Eftychiou et al. 2012). However, several studies reported contradicting findings. A cross sectional study showed neither high homocysteine nor lipoprotein (a) is associated with CAD in young women. However, a strong association with disease is found when both risk factors are present $(\mathrm{OR}=4.83$, $\mathrm{p}=0.003$ ). Homocysteine level and lipoprotein (a) are also independent risk factors for CAD in young men. The presence of both risk factors did not confer additional risk to the development of pCAD (Foody et al. 2000).

\section{APOLIPOPROTEIN}

The metabolism of apolipoprotein is closely associated with the development of atherosclerosis. In particular, apoA1 is the main component in high density lipoprotein (HDL) involved in reverse cholesterol transport (Yancey et al. 2003), whereas ApoE is a protein that mediates the transport and uptake of cholesterol and lipid (Saito et al. 2004). Furthermore, ApoB is a protein constituent of the atherogenic very low density lipoproteins (VLDL), intermediate density lipoproteins (IDL) and LDL (Ray et al. 2009). Measurement of plasma apolipoprotein allows an assessment of the total atherogenic and anti-atherogenic particles in the circulatory system. 
Patients with high ApoB and small density LDL have been reported to have three-fold increased risk of pCAD (StPierre et al. 2005). In genetic dyslipidemia, reduced ApoA1 levels and elevated ApoB levels predict pCAD (Ayyobi et al. 2007). A study of 203 pCAD patients examined the association between ApoB and ApoA1 with pCAD. ApoA1 is found to be independently associated with PCAD in men and plasma ApoB level is the strongest independent variable associated with pCAD in women (Kwiterovich et al. 1992). A similar finding was also reported involving 243 men and 61 women with pCAD and 203 age and sex-match controls. ApoB level has been found to be a predictor of risk in women (Weber et al. 1997). A study in non-diabetic pCAD patients showed that ApoB is a better marker than traditional lipids where ApoB concentrations is significantly higher in CAD group compared to normal $(102 \pm 24$ versus $84 \pm 17, \mathrm{p}<0.001)$ (Azizi et al. 2002). Therefore, measurement of ApoAI and ApoB levels may improve our ability to evaluate PCAD risk beyond lipid measurement.

\section{FIBRINOGEN AND FIBRIN}

Fibrinogen is the precursor of fibrin and considered to be a determinant for atherogenesis (Herrick et al. 1999). Multiple studies showed significant associations between CHD as well as cardiovascular disease (CVD) (Okwuosa et al. 2013). Fibrinogen circulates in the plasma and the normal concentration is $200-400 \mathrm{mg} / \mathrm{dL}$. However, fibrinogen levels can decline with lifestyle modifications such as exercise (Ernst 1993) and smoking cessation (Hunter et al. 2001). In young adults, fibrinogen also showed a positive association with most risk factors for cardiovascular disease. Fibrinogen level is positively associated with body mass index, cigarette smoking, LDL cholesterol, blood pressure and triglycerides while negatively associated with HDL cholesterol, alcohol intake and physical activity (Folsom et al. 1993).

The role of fibrin in PCAD was examined in a group of young, post myocardial infarction patients with angiographic proven CAD and in healthy volunteers matched for age and sex. Young CAD patients had significantly higher plasma fibrinogen, plasminogen activator inhibitor type I, von Willbrand factor and lipoprotein (a) as compared to controls. Fibrin of young patients was made of numerous and shorter fibres, stiffer and lysed at a slower rate than controls. Fibrin stiffness was found to be an independent predictor for both hypofibrinolysis and pCAD (Collet et al. 2006). High plasma fibrinogen also predicts critical coronary lesions in pCAD (Tatli et al. 2009). A case-control study conducted to discover the association between fibrinogen and premature myocardial infarction in middle age men less than 55 years old showed an elevated level of plasma fibrinogen in patients $(354.9 \pm 60 \mathrm{mg} / \mathrm{dL})$ compared to the control group $(329 \pm 73 \mathrm{mg} / \mathrm{dL})$. Hyperfibrinogenemia was found in $81.8 \%$ of the patients and $57.5 \%$ of controls $(\mathrm{OR}=3.3$, $\mathrm{p}=0.036$ ) (Shojaie et al. 2009). Essentially, in first degree relatives of patients with pCAD, a significant increase in fibrinogen levels has been demonstrated. These findings highlighted the importance of screening fibrinogen in healthy individuals who other than their family history, appeared to be at low risk in terms of conventional CAD risk factors (Mills et al. 2002).

\section{GAMMA GLUTAMYL TRANSFERASE (GGT)}

GGT is an enzyme present in the serum and on the outer surface of cells. It is responsible for the synthesis of extracellular glutathione (Shabbir et al. 2011). GGT levels are examined for liver and gallbladder diagnosis, especially for alcoholic related disease. Recent evidence suggests that increased serum gamma glutamyl transferase (GGT) is associated with cardiovascular disease (Mao et al. 2014). A number of epidemiological studies partly explained the correlation of GGT with multiple risk factors including obesity, hypertension, diabetes and metabolic syndrome suggesting it might participate in oxidative and inflammatory reactions (Lee et al. 2003; Nakanishi et al. 2004; Onat et al. 2012). Relationship between GGT activity and cardiovascular incidents had also been shown to be independent of alcohol intake in a meta-analysis (Fraser et al. 2007). However, the exact mechanism that relates GGT and cardiovascular disease is still unclear. Several hypotheses have been proposed including GGT itself is pro-atherogenic (Emdin et al. 2005) and elevated GGT is a marker for metabolic syndrome (Lee et al. 2007).

In established CAD patients, GGT is independently associated with increased arterial stiffness in both men and women (Zhu et al. 2013). Moreover, the increased GGT activity is related to clinical stability, LV function and inflammatory activity rather than the CAD severity (Demircan et al. 2009). Shabbir et al. (2011) reported the association of GGT activity with pCAD in young Pakistani patients (age $<45$ years old) who went for angiography. Their results showed that GGT activity was positively correlated with higher blood pressure, glucose, smoking and cholesterol and negatively correlated with antioxidant status. Furthermore, GGT activity increased significantly in PCAD compared to controls. Their findings suggest a good diagnostic accuracy at cut-off of $35 \mathrm{U} / \mathrm{L}$, with $81 \%$ specificity, $92 \%$ sensitivity and diagnostic odds ratio of 48 for prediction of PCAD in young Pakistanis.

\section{SYMMETRIC AND ASSYMETRICDIMETHYLARGININE (SDMA AND ADMA)}

Assymetricdimethylarginine (ADMA) is an endogenous inhibitor for nitric oxide synthase and regulates the rate of NO production (Leiper \& Vallance 1999). ADMA has been regarded as a potential biomarker for cardiovascular disease and may potentially influence restenosis after angioplasty (Derkacz et al. 2011). Moreover, among young healthy subjects, ADMA has been suggested to have a role in regulating systemic vascular tone (Paiva et al. 2008). Studies on ADMA associated risk in smokers and non-smokers showed an adjusted relative risk for future 
coronary events of 2.40 (95\% CI 1.14-5.08; $\mathrm{p}=0.021)$ in non-smokers and 0.48 (95\% CI 0.16-1.46; $\mathrm{p}=0.198)$ in smokers. It was suggested that ADMA metabolism may be altered by tobacco smoke (Maas et al. 2007). A follow-up study involving 1148 coronary heart disease patients showed ADMA is not associated with secondary CVD events. After 8 years, 150 patients had a secondary event and 121 patients died and an association was only suggested for symmetricdimethylarginine (SDMA) (HR 1.17 [1.00-1.37]) (Siegerink et al. 2013). SDMA levels also have been shown to be independently associated with increased cardiovascular and all-cause mortality in subjects undergoing coronary angiography (Meinitzer et al. 2011). The differences in terms of the risk pattern in SDMA and ADMA suggest both methylarginines have unique pathophysiological roles in CAD.

A study on a population of young Indians (age between 15 and 50 years) showed plasma ADMA concentrations in patients with ischemic stroke were significantly higher compared to age matched controls ( 1.49 vs. $0.97 \mu \mathrm{mol} / 1$, $\mathrm{p}<0.001)$. The association with stroke remained significant even after adjustment with cardiovascular risk factors $(\mathrm{OR}=1.55,95 \%$ CI 1.25-1.92, $\mathrm{p}<0.001)$ (Mamatha et al. 2011). In another study on young Egyptians (age between 35 and 50 years old), only SDMA level is significantly elevated in patients. However, when comparing between chronic (patients who went for medical treatment, PCI or $\mathrm{CABG}$ ) and acute (patients with acute myocardial infarction) patients, both ADMA and SDMA levels were significantly higher only in acute patients ( Gad et al. 2010).

\section{GENETIC POLYMORPHISMS AS BIOMARKERS}

The development of atherosclerosis involves both environmental and genetic factors. Beside traditional risk factors such as smoking, physical activity and dietary, clinical outcome can be influenced by genetic variants. Recent genome-wide association studies have reported 35 common genetic variants associated with CAD in European population (Peden \& Farrall 2011) which were replicated in Japan and Korean populations (Lee et al. 2013). Although the main contribution for these genome-wide scans is to identify possible mechanisms and pathways leading to the disease thus offering potential intervention, the usefulness of the SNPS as predictive biomarkers has been demonstrated in a few studies (Kathiresan et al. 2008; Ripatti et al. 2010). Several SNPs also showed significant association with PCAD providing further support of the potential of SNPs for PCAD (Table 2).

A previous study reported the association of 48 coding and 3 non-coding SNPs from 35 inflammatory genes with CAD. Significant association was observed between three locus haplotype in interleukin 1 cluster with $\mathrm{p}=0.006$ in all CAD cases, $\mathrm{p}=0.01$ in myocardial infarction and $\mathrm{p}=0.0002$ in pCAD (Brown et al. 2010). After adjusting for traditional risk factors including sex, smoking, hypertension and hypercholesterolemia, the haplotype effect remained significant in PCAD cases. A cross-sectional, observational study conducted in pCAD patients and controls with a mean age below 45 years to determine the effect of IL-10 gene promoter polymorphism showed no relationship between polymorphism and adverse angiographic and clinical outcome, but found a significant difference in IL-10 -592C/A allelic frequency ( $\mathrm{OR}=2.00,95 \%$ CI $0.9434-4.2579)$ between patients and match controls (Karaca et al.2011). However, in contrast, Cardiovascular Risk in Young Finns Study reported an inverse association in arterial stiffness index $(p=0.0034)$ and Young's elastic modulus $(\mathrm{p}=0.0005)$ demonstrating discordance with the supposed anti-atherogenic properties of IL-10 (Heiskanen et al. 2010).

Similarly, IL-6 polymorphisms also showed conflicting findings. A study of Pakistani families involving 36 patients with mean age of $46.4 \pm 18.7$ showed IL-6 polymorphism at-174 was more prevalent in CAD cases compared to healthy controls. There was significant association between IL- 6 polymorphism and CAD suggesting an association with an increased risk for the disease (Satti et al. 2013). In multi-ethnic comparison, the -174 IL-6 allele frequency was higher in young Indians (23\%) compared to Black participants (2\%) with $\mathrm{p}<0.0001$ (OR $=0.05,95 \%$ CI $0.018-0.14)$. A significant association with CAD has also been found among young Indian patients when compared to control. However, several studies found no association of IL-6 with CAD (Ghazouani et al. 2011; Sekuri et al. 2007). Nevertheless, single nucleotide polymorphism may offer predictive value for predisposition to $\mathrm{PCAD}$.

\section{MICRO-RNA (MIRNA)}

Small non coding RNAs (miRNA) are typically 20 to 26 nucleotides long which function mainly in regulation of post-transcriptional gene expression. As such, miRNA plays multiple roles in preserving biological processes including cell proliferation, apoptosis and tumorigenesis (Cordes \& Srivastava 2009). In recent years, interest has escalated on miRNA as a potential biomarker as well as a potential therapeutic approach for cardiovascular disease (De Rosa et al. 2014; Hagiwara et al. 2014; Olson 2014). Numerous studies have been conducted on circulating miRNA in either acute myocardial infarction or CAD (Table 3 ). For instance, 11 miRNAs have been found significantly downregulated among CAD patients compared to healthy controls. Although medication used may alter the relative miRNA expression, these results have implications in the use of miRNA for identifying and managing individuals with $\mathrm{CAD}$ or at higher risk of developing disease (Weber et al. 2011).

A case control study investigated the role of miRNA in pCAD by comparing relative expression levels of platelet miRNAs using microarrays (Sondermeijer et al. 2011). Six platelet miRNAs were significantly upregulated in pCAD (miR340, miR451, miR454, miR545:9.1. miR615$5 \mathrm{p}$ and miR624) while one miRNA (miR1280) was downregulated compared to controls. Validation studies in 


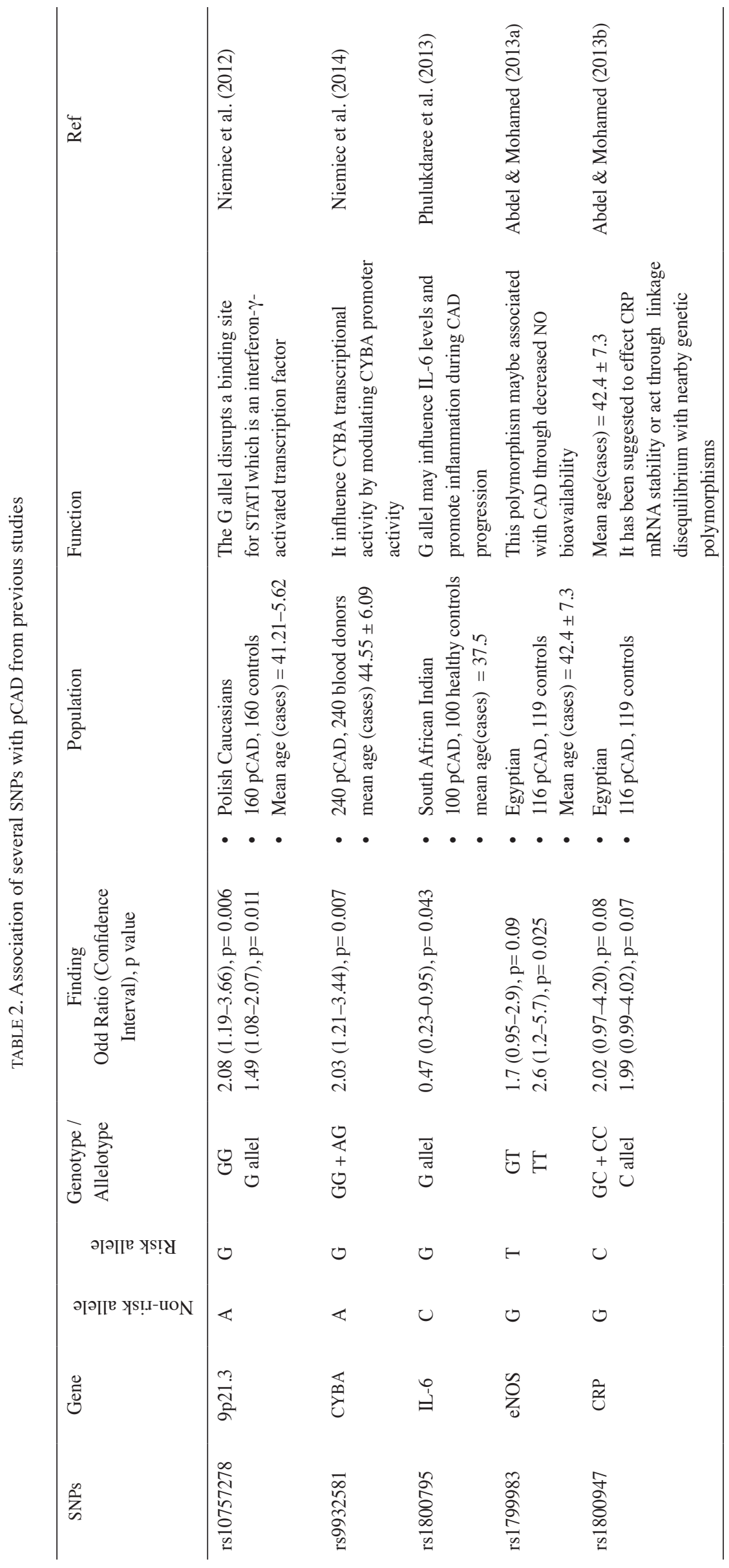




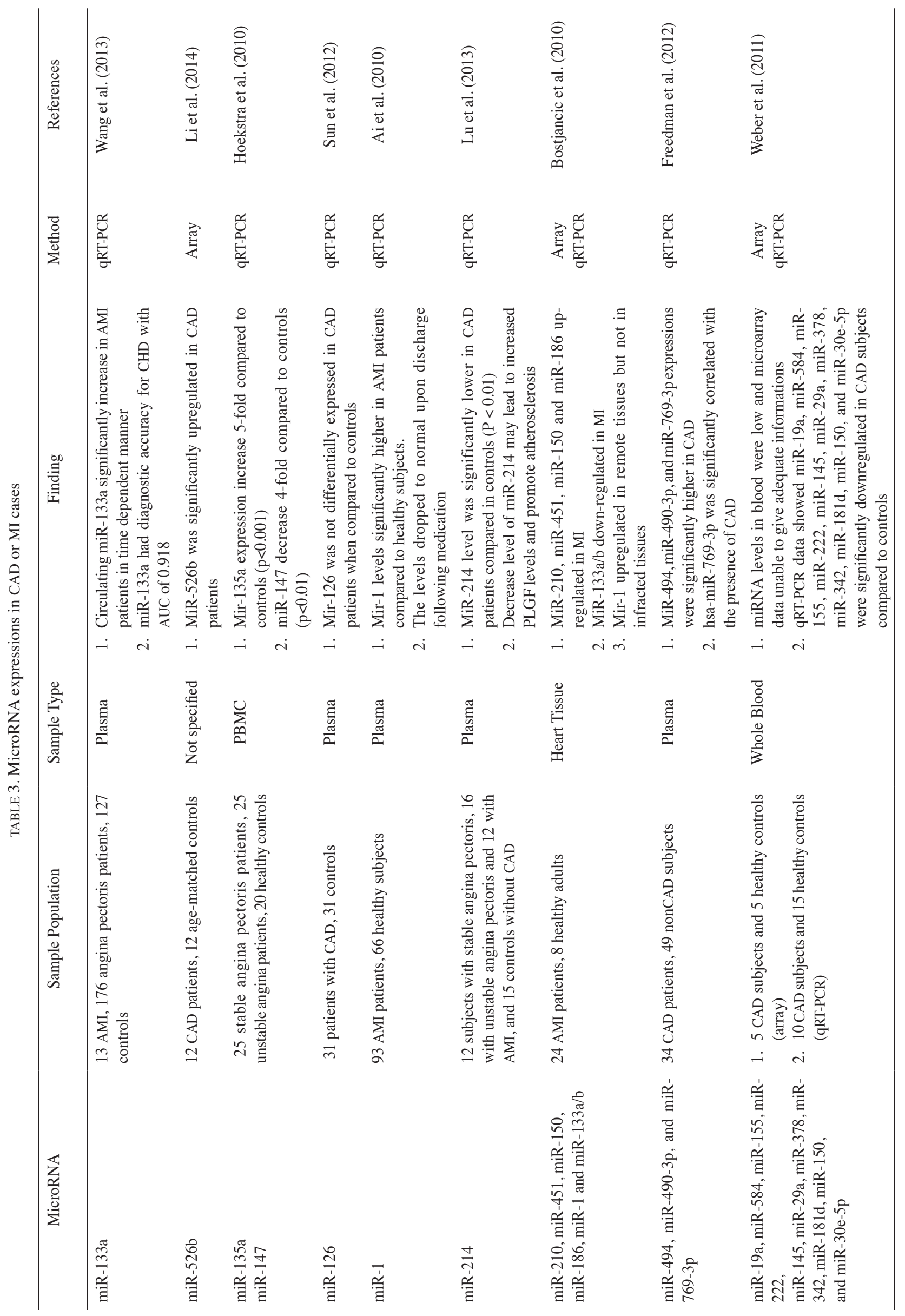


two different cohorts confirmed that miR340 and miR624 were upregulated in PCAD. However the limitation of this study is that the differences in miRNA expression levels between patients and controls were very small. It is difficult to determine if both miRNAs can be used as independent biomarkers for pCAD. Taken together, miRNAs have the potential utility to be novel biomarkers in CAD particularly in younger adults. However, further studies conducted using larger cohorts are necessary to evaluate and prove their candidacy as predictors for PCAD.

\section{CONCLUSION}

Understanding the mechanism of atherogenesis including lipid metabolism, endothelial dysfunction, oxidative stress and inflammation may be crucial if prevention strategies are to be targeted accurately. The usual risk factors of age, sex, family history, cholesterol level, smoking status, blood pressure and diabetes may be insufficient to predict risk to pCAD. The emergence of omics technology offer extensive information on the genes and proteins involved during disease progression and as such, can be potential biomarkers for CAD. As protein markers give an insight on the actual body condition, genetic markers might be a better marker for risk assessment. Knowledge at the genome level such as polymorphism can enhance our ability to identify high risk individuals as genomic data provide the information on susceptibility to disease particularly pCAD. A well-designed clinical trial should be conducted in order to properly validate their candidacy and maximize their potential as biomarkers.

A good biomarker should be highly sensitive and specific to be used clinically. Although many biomarkers for CAD such as homocysteine, IL-6 or ApoB/ApoA1 ratio have been proposed, none are routinely used in diagnostic procedure except for CRP. Perhaps one of the reasons is because of evidence insufficiency from prospective cohort studies. As CAD is a complex disease that involves multiple stages and interactions, relying on one biomarker might be inadequate. The ideal alternative is to introduce a panel of biomarkers that provide a risk score or algorithm and evaluate the predisposition to pCAD so that early preventive measures and lifestyle modifications can be done. Nevertheless, recent data on potential biomarkers for PCAD can provide the basis for studies to further justify their prognostic value. Future studies should take the next step for risk prediction including in the determination of their role during disease progression as well as establishing markers to be used routinely.

\section{ACKNOWLEDGEMENTS}

We thank our colleagues from National University of Malaysia and National Heart Institute of Malaysia for comments that greatly improved the manuscript. The authors declare no conflict of interest in this review.

\section{REFERENCES}

Abdel-Aziz, T.A. \& Mohamed, R.H. 2013a. Association of endothelial nitric oxide synthase gene polymorphisms with classical risk factors in development of premature coronary artery disease. Molecular Biology Reports 40(4): 3065-3071.

Abdel-Aziz, T.A. \& Mohamed, R.H. 2013b. Human C-reactive protein gene polymorphism and metabolic syndrome are associated with premature coronary artery disease. Gene 532(2): 216-221.

Ahmad, W.A., Ali, R.M., Khanom, M., Han, C.K., Bang, L.H., Yip, A.F., Ghazi, A.M., Ismail, O., Zambahari, R. \& Hian, S.K. 2013. The journey of Malaysian Ncvd-Pci (National Cardiovascular Disease Database-Percutaneous Coronary Intervention) Registry: A Summary of three years report. Int . J. Cardiol. 165(1): 161-164.

Ai, J., Zhang, R., Li, Y., Pu, J., Lu, Y., Jiao, J., Li, K., Bo, Yu., Li, Z., Wang, R., Wang, L., Li, Q., Wang, N., Shan, H., Li, Z. \& Yang, B. 2010. Circulating microRNA-1 as a potential novel biomarker for acute myocardial infarction. Biochemical and Biophysical Research Communications 391(1): 73-77.

Albert, C.M.,Cook, N.R., Gaziano, J.M.,Zaharris, E., Macfadyen, J., Danielson, E., Buring, J.E. \& Manson, J.E. 2008. Effect of folic acid and $b$ vitamins on risk of cardiovascular events and total mortality among women at high risk for cardiovascular disease: A randomized trial. JAMA 299(17): 2027-2036.

Armitage, J.M., Bowman, L., Clarke, R.J., Wallendszus, K., Bulbulia, R., Rahimi, K., Haynes, R., Parish, S., Sleight, P., Peto, R. \& Collins, R. 2010. Effects of homocysteinelowering with folic acid plus vitamin b12 vs placebo on mortality and major morbidity in myocardial infarction survivors: A randomized trial. JAMA 303(24): 2486-2494.

Arzamendi, D., Benito, B., Tizon-Marcos, H., Flores, J., Tanguay, J.F., Ly, H., Doucet, S., Leduc, L., Leung, T.K., Campuzano, O., Iglesias, A., Talajic, M. \& Brugada, R. 2011. Increase in sudden death from coronary artery disease in young adults. Am. Heart J. 161(3): 574-580.

Ayyobi, A.F., Zambon, A. \& Brunzell, J.D. 2007. Premature coronary artery disease and apolipoprotein $b$ and apolipoprotein a-i. International Congress Series 1303: 85-94.

Azizi, F., Rahmani, M., Raiszadeh, F., Solati, M. \& Navab, M. 2002. Association of lipids, lipoproteins, apolipoproteins and paraoxonase enzyme activity with premature coronary artery disease. Coron. Artery Dis. 13(1): 9-16.

Bostjancic, E., Zidar, N., Stajner, D. \& Glavac, D. 2010. MicroRNA miR-1 is up-regulated in remote myocardium in patients with myocardial infarction. Folia biologica 56(1): 27-31.

Brown, B.D., Nsengimana, J., Barrett, J.H., Lawrence, R.A., Steiner, L., Cheng, S., Bishop, D.T., Samani, N.J., Ball, S.G., Balmforth, A.J. \& Hall, A.S. 2010. An evaluation of inflammatory gene polymorphisms in sibships discordant for premature coronary artery disease: The grace-immune study. BMC Med. 8: 5. https://doi.org/10.1186/1741-7015-8-5.

Castelli, W.P. 1996. Lipids, risk factors and ischaemic heart disease. Atherosclerosis 124: S1-S9.

Che, J., Li, G., Shao, Y., Niu, H. \& Shi, Y. 2013. An analysis of the risk factors for premature coronary artery disease in young and middle-age chinese patients with hypertension. Exp. Clin. Cardiol. 18(2): 89-92.

Choi, J., Daskalopoulou, S.S., Thanassoulis, G., Karp, I., Pelletier, R., Behlouli, H., Pilote, L. \& Investigators, G.P. 
2014. Sex- and gender-related risk factor burden in patients with premature acute coronary syndrome. Can. J. Cardiol. 30(1): 109-117.

Christus, T., Shukkur, A.M., Rashdan, I., Koshy, T., Alanbaei, M., Zubaid, M., Hayat, N. \& Alsayegh, A. 2011. Coronary artery disease in patients aged 35 or less - A different beast? Heart Views 12(1): 7-11.

Collet, J.P., Allali, Y., Lesty, C., Tanguy, M.L., Silvain, J., Ankri, A., Blanchet, B., Dumaine, R., Gianetti, J., Payot, L., Weisel, J.W. \& Montalescot, G. 2006. Altered fibrin architecture is associated with hypofibrinolysis and premature coronary atherothrombosis. Arterioscler. Thromb. Vasc. Biol.26(11): 2567-2573.

Cordes, K.R. \& Srivastava, D. 2009. Microrna regulation of cardiovascular development. Circ. Res. 04(6): 724-732.

Cunningham, K.S. \& Gotlieb, A.I. 2005. The role of shear stress in the pathogenesis of atherosclerosis. Lab. Invest. 85(1): 9-23.

De Rosa, S., Curcio, A. \& Indolfi, C. 2014. Emerging role of micrornas in cardiovascular diseases. Circ.J.78(3): 567-575.

Demircan, S., Yazici, M., Durna, K., Kilicaslan, F., Demir, S., Pinar, M. \& Gulel, O. 2009. The importance of gammaglutamyltransferase activity in patients with coronary artery disease. Clin. Cardiol. 32(4): 220-225.

Derkacz,A.,Protasiewicz, M., Poreba, R., Doroszko, A., Poreba, M., Antonowicz-Juchniewicz, J., Andrzejak, R. \& Szuba, A. 2011. Plasma asymmetric dimethylarginine predicts restenosis after coronary angioplasty. Arch. Med.Sci. 7(3): 444-448.

Dey, S., Flather, M.D., Devlin, G., Brieger, D., Gurfinkel, E.P., Steg, P.G., Fitzgerald, G., Jackson, E.A., Eagle, K.A. \& Global Registry of Acute Coronary Events, I. 2009. Sex-related differences in the presentation, treatment and outcomes among patients with acute coronary syndromes: The global registry of acute coronary events. Heart 95(1): 20-26.

Dobrovolskienė, R., Mockevičienė, G., Urbonaitė, B., Jurgevičienè, N., Preikša, R.T. \& Ostrauskas, R. 2013. The risk of early cardiovascular disease in lithuanian diabetic children and adolescents: A type 1 diabetes register database based study. Diabetes Research and Clinical Practice 100(1): 119-125.

Eftychiou, C., Antoniades, L., Makri, L., Koumas, L., Costeas, P.A., Kyriakou, E., Nicolaides, E. \& Papadogiannis, D. 2012. Homocysteine levels and mthfr polymorphisms in young patients with acute myocardial infarction: A case control study. Hellenic J. Cardiol. 53(3): 189-194.

Egiziano, G., Akhtari, S., Pilote, L., Daskalopoulou, S.S. \& Investigators, G. 2013. Sex differences in young patients with acute myocardial infarction. Diabet.Med.30(3): e108-e114.

Emdin, M., Pompella, A. \& Paolicchi, A. 2005. Gammaglutamyltransferase, atherosclerosis, and cardiovascular disease: Triggering oxidative stress within the plaque. Circulation 112(14): 2078-2080.

Ernst, E. 1993. Regular exercise reduces fibrinogen levels: A review of longitudinal studies. Br. J. Sports. Med. 27(3): 175-176.

Faraci, F.M. 2003. Hyperhomocysteinemia: A million ways to lose control.Arterioscler. Thromb. Vasc. Biol.23(3): 371-373.

Folsom, A.R., Qamhieh, H.T., Flack, J.M., Hilner, J.E., Liu, K., Howard, B.V. \& Tracy, R.P. 1993. Plasma fibrinogen: Levels and correlates in young adults. The coronary artery risk development in young adults (cardia) study. Am. $J$. Epidemiol. 138(12): 1023-1036.
Foody, J.M., Milberg, J.A., Robinson, K., Pearce, G.L., Jacobsen, D.W. \& Sprecher, D.L. 2000. Homocysteine and lipoprotein(a) interact to increase cad risk in young men and women. Arterioscler. Thromb. Vasc. Biol. 20(2): 493-499.

Fraser, A., Harris, R., Sattar, N., Ebrahim, S., Smith, G.D. \& Lawlor, D.A. 2007. Gamma-glutamyltransferase is associated with incident vascular events independently of alcohol intake: Analysis of the british women's heart and health study and meta-analysis. Arterioscler. Thromb. Vasc. Biol. 27(12): 2729-2735.

Freedman, J.E., Ercan, B., Morin, K.M., Liu, C.T., Tamer, L., Ayaz, L., Kanadasi, M., Cicek, D., Seyhan, A.I., Akilli, R.E., Camci, C., Cengiz, B., Oztuzcu, S. \& Tanriverdil Kahraman. 2012. The distribution of circulating microRNA and their relation to coronary disease. F1000 Research 1: 50.

Gad, M.Z., Hassanein, S.I., Abdel-Maksoud, S.M., Shaban, G.M., Abou-Aisha, K. \& Elgabarty, H.A. 2010. Assessment of serum levels of asymmetric dimethylarginine, symmetric dimethylarginine and 1-arginine in coronary artery disease. Biomarkers 15(8): 746-752.

Ghazouani, L., Abboud, N., Ben Hadj Khalifa, S., Added, F., Ben Khalfallah, A., Nsiri, B., Mediouni, M. \& Mahjoub, T. 2011. $-174 \mathrm{~g}>\mathrm{c}$ interleukin-6 gene polymorphism in tunisian patients with coronary artery disease. Ann. Saudi Med.31(1): 40-44.

Goff, D.C., Jr., Lloyd-Jones, D.M., Bennett, G., Coady, S., D'agostino, R.B., Gibbons, R., Greenland, P., Lackland, D.T., Levy, D., O'donnell, C.J., Robinson, J.G., Schwartz, J.S., Shero, S.T., Smith, S.C., Jr., Sorlie, P., Stone, N.J., Wilson, P.W., Jordan, H.S., Nevo, L., Wnek, J., Anderson, J.L., Halperin, J.L., Albert, N.M., Bozkurt, B., Brindis, R.G., Curtis, L.H., Demets, D., Hochman, J.S., Kovacs, R.J., Ohman, E.M., Pressler, S.J., Sellke, F.W., Shen, W.K., Smith, S.C., Jr., Tomaselli, G.F. \& American College of Cardiology/American Heart Association Task Force on Practice, G. 2014. 2013 acc/aha guideline on the assessment of cardiovascular risk: A report of the american college of cardiology/american heart association task force on practice guidelines. Circulation 129: S49-S73.

Graham, I.M., Daly, L.E., Refsum, H.M., Robinson, K., Brattstrom, L.E., Ueland,P.M., Palma-Reis, R.J., Boers, G.H., Sheahan, R.G., Israelsson, B., Uiterwaal, C.S., Meleady, R., Mcmaster, D., Verhoef, P., Witteman, J., Rubba, P., Bellet, H., Wautrecht, J.C., De Valk, H.W., Sales Luis, A.C., ParrotRouland, F.M., Tan, K.S., Higgins, I., Garcon, D. \& Andria, G. 1997. Plasma homocysteine as a risk factor for vascular disease. The European concerted action project. JAMA 277(22): 1775-1781

Gupta, S.K., Kotwal, J., Kotwal, A., Dhall, A. \& Garg, S. 2012. Role of homocysteine \& mthfr c677t gene polymorphism as risk factors for coronary artery disease in young indians. Indian J. Med. Res.135(4): 506-512.

Hagiwara, S., Kantharidis, P. \& Cooper, M.E. 2014. Microrna as biomarkers and regulator of cardiovascular development and disease. Curr. Pharm. Des. 20(14): 2347-2370.

Hbejan, K. 2011. Smoking effect on ischemic heart disease in young patients. Heart Views 12(1): 1-6.

Heiskanen, M., Kahonen, M., Hurme, M., Lehtimaki, T., Mononen, N., Juonala, M., Hutri-Kahonen, N., Viikari, J., Raitakari, O. \& Hulkkonen, J. 2010. Polymorphism in the il10 promoter region and early markers of atherosclerosis: The cardiovascular risk in young finns study. Atherosclerosis 208(1): 190-196.

Herrick, S., Blanc-Brude, O., Gray, A. \& Laurent, G. 1999. Fibrinogen. Int. J. Biochem. Cell. Biol. 31(7): 741-746. 
Hoekstra, M., van der Lans, C.A., Halvorsen, B., Gullestad, L., Kuiper, J., Aukrust, P., van Berkela, T.J.C. \& Biessenae, E.A.L. 2010. The peripheral blood mononuclear cell microRNA signature of coronary artery disease. Biochemical and Biophysical Research Communications 394(3): 792-797.

Hozawa, A., Houston, T., Steffes, M.W., Widome, R., Williams, O.D., Iribarren, C., Pletcher, M.J., Daviglus, M.L., Carr, J.J. \& Jacobs, D.R.,Jr. 2006. The association of cigarette smoking with self-reported disease before middle age: The coronary artery risk development in young adults (cardia) study. Prev. Med. 42(3): 193-199.

Hunter, K.A., Garlick, P.J., Broom, I., Anderson, S.E. \& Mcnurlan, M.A. 2001. Effects of smoking and abstention from smoking on fibrinogen synthesis in humans. Clin. Sci. (Lond) 100(4): 459-465.

Karaca, E., Kayikcioglu, M., Onay, H., Gunduz, C. \& Ozkinay, F. 2011. The effect of interleukin-10 gene promoter polymorphisms on early-onset coronary artery disease. Anadolu Kardiyol. Derg. 11(4): 285-289.

Kathiresan, S., Melander, O., Anevski, D., Guiducci, C., Burtt, N.P., Roos, C., Hirschhorn, J.N., Berglund, G., Hedblad, B., Groop, L., Altshuler, D.M., Newton-Cheh, C. \& Orho-Melander, M. 2008. Polymorphisms associated with cholesterol and risk of cardiovascular events. N. Engl. J. Med. 358(12): 1240-1249.

Kaul, S., Zadeh, A.A. \& Shah, P.K. 2006. Homocysteine hypothesis for atherothrombotic cardiovascular disease: Not validated. J. Am. Coll. Cardiol. 48(5): 914-923.

Kunjathoor, V.V., Febbraio, M., Podrez, E.A., Moore, K.J., Andersson, L., Koehn, S., Rhee, J.S., Silverstein, R., Hoff, H.F. \& Freeman, M.W. 2002. Scavenger receptors class a-i/ii and $\operatorname{cd} 36$ are the principal receptors responsible for the uptake of modified low density lipoprotein leading to lipid loading in macrophages. J. Biol. Chem. 277(51): 49982-49988.

Kwiterovich, P.O., Jr., Coresh, J., Smith, H.H., Bachorik, P.S., Derby, C.A. \& Pearson, T.A. 1992. Comparison of the plasma levels of apolipoproteins $\mathrm{b}$ and $\mathrm{a}-1$, and other risk factors in men and women with premature coronary artery disease. Am. J. Cardiol. 69(12): 1015-1021.

Lansky, A.J., Ng, V.G., Maehara, A., Weisz, G., Lerman, A., Mintz, G.S., De Bruyne, B., Farhat, N., Niess, G., Jankovic, I., Lazar, D., Xu, K., Fahy, M., Serruys, P.W. \& Stone, G.W. 2012. Gender and the extent of coronary atherosclerosis, plaque composition, and clinical outcomes in acute coronary syndromes. JACC Cardiovasc. Imaging 5(3): S62-S72.

Lee, D.H., Jacobs, D.R., Jr., Gross, M., Kiefe, C.I., Roseman, J., Lewis, C.E. \& Steffes, M. 2003. Gamma-glutamyltransferase is a predictor of incident diabetes and hypertension: The coronary artery risk development in young adults (cardia) study. Clin. Chem. 49(8): 1358-1366.

Lee, D.S., Evans, J.C., Robins, S.J., Wilson, P.W., Albano, I., Fox, C.S., Wang, T.J., Benjamin, E.J., D'agostino, R.B. \& Vasan, R.S. 2007. Gamma glutamyl transferase and metabolic syndrome, cardiovascular disease, and mortality risk: The framingham heart study. Arterioscler. Thromb. Vasc. Biol. 27(1): 127-133.

Lee, J.Y., Lee, B.S., Shin, D.J., Woo Park, K., Shin, Y.A., Joong Kim, K., Heo, L., Young Lee, J., Kyoung Kim, Y., Jin Kim, Y., Bum Hong, C., Lee, S.H., Yoon, D., Jung Ku, H., Oh, I.Y., Kim, B.J., Lee, J., Park, S.J., Kim, J., Kawk, H.K., Lee, J.E., Park, H.K., Lee, J.E., Nam, H.Y., Park, H.Y., Shin, C., Yokota, M., Asano, H., Nakatochi, M., Matsubara, T., Kitajima, H., Yamamoto, K., Kim, H.L., Han, B.G., Cho, M.C., Jang, Y.,
Kim, H.S., Euy Park, J. \& Lee, J.Y. 2013. A genome-wide association study of a coronary artery disease risk variant. $J$. Hum. Genet. 58(3): 120-126.

Leiper, J. \& Vallance, P. 1999. Biological significance of endogenous methylarginines that inhibit nitric oxide synthases. Cardiovasc. Res. 43(3): 542-548.

Li, K., Zhang, T., Fan, H., Li, Q., Ito, W., Torzewski, J., Guo, J. \& Liu,Z. 2014. The analysis of microRNA expression profiling for coronary artery disease. Cardiology 127(1): 62-69.

Libby, P. 2012. Inflammation in atherosclerosis. Arterioscler. Thromb. Vasc. Biol. 32(9): 2045-2051.

Lin, J., Kakkar, V. \& Lu, X. 2014. Impact of matrix metalloproteinases on atherosclerosis. Curr. Drug Targets 15(4): 442-453.

Lloyd-Jones, D.M., Nam, B.H., D’agostino, R.B., Sr., Levy, D., Murabito, J.M., Wang, T.J., Wilson, P.W. \& O'donnell, C.J. 2004. Parental cardiovascular disease as a risk factor for cardiovascular disease in middle-aged adults: A prospective study of parents and offspring. JAMA 291(18): 2204-2211.

Lu, H.Q., Liang, C., He, Z.Q., Fan, M. \& Wu, Z.G. 2013. Circulating miR-214 is associated with the severity of coronary artery disease. Journal of Geriatric Cardiology: JGC. 10(1): 34-38

Lu, H.T. \& Nordin, R.B. 2013. Ethnic differences in the occurrence of acute coronary syndrome: Results of the Malaysian national cardiovascular disease (ncvd) database registry (March 2006- February 2010). BMC Cardiovasc. Disord. 13(1): 97. doi: 10.1186/1471-2261-13-97.

Maas, R., Schulze, F., Baumert, J., Lowel, H., Hamraz, K., Schwedhelm, E., Koenig, W. \& Boger, R.H. 2007. Asymmetric dimethylarginine, smoking, and risk of coronary heart disease in apparently healthy men: Prospective analysis from the population-based monitoring of trends and determinants in cardiovascular disease/kooperative gesundheitsforschung in der region augsburg study and experimental data. Clin. Chem. 53(4): 693-701.

Madamanchi, N.R., Vendrov, A. \& Runge, M.S. 2005. Oxidative stress and vascular disease. Arterioscler.Thromb. Vasc. Biol. 25(1): 29-38.

Mamatha, S.N., Nagaraja, D., Philip, M. \& Christopher, R. 2011. Asymmetric dimethylarginine as a risk marker for earlyonset ischemic stroke in Indian population. Clin. Chim. Acta. 412(1-2): 139-142.

Mao, Y., Qi, X., Xu, W., Song, H., Xu, M., Ma, W. \& Zhou, L. 2014. Serum gamma-glutamyl transferase: A novel biomarker for coronary artery disease. Med.Sci. Monit. 20: 706-710.

Meinitzer, A., Kielstein, J.T., Pilz, S., Drechsler, C., Ritz, E., Boehm, B.O., Winkelmann, B.R. \& Marz, W. 2011. Symmetrical and asymmetrical dimethylarginine as predictors for mortality in patients referred for coronary angiography: The ludwigshafen risk and cardiovascular health study. Clin Chem. 57(1): 112-121.

Milcent, C., Dormont, B., Durand-Zaleski, I. \& Steg, P.G 2007. Gender differences in hospital mortality and use of percutaneous coronary intervention in acute myocardial infarction: Microsimulation analysis of the 1999 nationwide French hospitals database. Circulation 115(7): 833-839.

Mills, J., Mansfield, M. \& Grant, P. 2002. Elevated fibrinogen in the healthy male relatives of patients with severe, premature coronary artery disease. Eur. Heart J. 23(16): 1276-1281.

Mohan, V., Deepa, R., Rani, S.S., Premalatha, G. \& Chennai Urban Population, S. 2001. Prevalence of coronary artery 
disease and its relationship to lipids in a selected population in south india: The chennai urban population study (cups no. 5). J. Am. Coll. Cardiol. 38(3): 682-687.

Morillas, P., Bertomeu, V., Pabon, P., Ancillo, P., Bermejo, J., Fernandez, C., Aros, F. \& Investigators, P.I. 2007. Characteristics and outcome of acute myocardial infarction in young patients. The priamho ii study. Cardiology 107(4): 217-225.

Nakanishi, N., Suzuki, K. \& Tatara, K. 2004. Serum gammaglutamyltransferase and risk of metabolic syndrome and type 2 diabetes in middle-aged Japanese men. Diabetes Care 27(6): 1427-1432.

Napoli, C., D'armiento, F.P., Mancini, F.P., Postiglione, A., Witztum, J.L., Palumbo, G. \& Palinski, W. 1997. Fatty streak formation occurs in human fetal aortas and is greatly enhanced by maternal hypercholesterolemia. Intimal accumulation of low density lipoprotein and its oxidation precede monocyte recruitment into early atherosclerotic lesions. J. Clin. Invest. 100(11): 2680-2690.

Naya, M., Morita, K., Yoshinaga, K., Manabe, O., Goto, D., Hirata, K., Katoh, C., Tamaki, N. \& Tsutsui, H. 2011. Longterm smoking causes more advanced coronary endothelial dysfunction in middle-aged smokers compared to young smokers. Eur. J. Nucl. Med. Mol. Imaging 38(3): 491-498.

Nichols, M., Townsend, N., Scarborough, P. \& Rayner, M. 2014. Cardiovascular disease in Europe 2014: Epidemiological update. Eur. Heart J. 35(42): 2950-2959.

Niemiec, P., Gorczynska-Kosiorz, S., Iwanicki, T., Krauze, J., Trautsolt, W., Grzeszczak, W., Bochenek, A. \& Zak, I. 2012. The rs 10757278 polymorphism of the 9 p21.3 locus is associated with premature coronary artery disease in Polish patients. Genetic Testing and Molecular Biomarker 16(9): 1080-1085.

Niemiec, P., Nowak, T., Iwanicki, T., Krauze, J., GorczynskaKosiorz, S., Grzeszczak, W., Ochalska-Tyka, A. \& Zak, I. 2014. The $-930 A>G$ polymorphism of the CYBA gene is associated with premature coronary artery disease. A casecontrol study and gene-risk factors interactions. Molecular Biology Reports 41(5): 3287-3294.

Okwuosa, T.M., Klein, O., Chan, C., Jenny, N.S., Schreiner, P., Green, D. \& Liu, K. 2013. 13-year long-term associations between changes in traditional cardiovascular risk factors and changes in fibrinogen levels: The coronary artery risk development in young adults (cardia) study. Atherosclerosis 226(1): 214-219.

Olson, E.N. 2014. Micrornas as therapeutic targets and biomarkers of cardiovascular disease. Sci.Transl.Med. 6(239): 239-233.

Onat, A., Can, G., Ornek, E., Cicek, G., Ayhan, E. \& Dogan, Y. 2012. Serum gamma-glutamyltransferase: Independent predictor of risk of diabetes, hypertension, metabolic syndrome, and coronary disease. Obesity (Silver Spring) 20(4): 842-848.

Otaki, Y., Gransar, H., Berman, D.S., Cheng, V.Y., Dey, D., Lin, F.Y., Achenbach, S., Al-Mallah, M., Budoff, M.J., Cademartiri, F., Callister, T.Q., Chang, H.J., Chinnaiyan, K., Chow, B.J., Delago, A., Hadamitzky, M., Hausleiter, J., Kaufmann, P., Maffei, E., Raff, G., Shaw, L.J., Villines, T.C., Dunning, A. \& Min, J.K. 2013. Impact of family history of coronary artery disease in young individuals (from the confirm registry). Am. J. Cardiol. 111(8): 1081-1086.

Ozaki, K. \& Leonard, W.J. 2002. Cytokine and cytokine receptor pleiotropy and redundancy. J. Biol. Chem. 277(33): 2935529358.
Paiva, H., Kahonen, M., Lehtimaki, T., Raitakari, O.T., Jula, A., Viikari, J., Alfthan, G., Juonala, M., Laaksonen, R. \& HutriKahonen, N. 2008. Asymmetric dimethylarginine (adma) has a role in regulating systemic vascular tone in young healthy subjects: The cardiovascular risk in young finns study. Am. J. Hypertens. 21(8): 873-878.

Peden, J.F. \& Farrall, M. 2011. Thirty-five common variants for coronary artery disease: The fruits of much collaborative labour. Hum. Mol. Genet. 20(R2): R198-R205.

Pineda, J., Marin, F., Roldan, V., Valencia, J., Marco, P. \& Sogorb, F. 2008. Premature myocardial infarction: Clinical profile and angiographic findings. Int. J. Cardiol. 126(1): 127-129.

Phulukdaree, A., Khan, S., Ramkaran, P., Govender, R., Moodley, D. \& Chuturgoon, A.A. 2013. The interleukin-6 -147 g/c polymorphism is associated with increased risk of coronary artery disease in young South African Indian men. Metabolic Syndrome and Related Disorders 11(3): 205-209.

Poon, S., Goodman, S.G., Yan, R.T., Bugiardini, R., Bierman, A.S., Eagle, K.A., Johnston, N., Huynh, T., Grondin, F.R., Schenck-Gustafsson, K. \& Yan, A.T. 2012. Bridging the gender gap: Insights from a contemporary analysis of sexrelated differences in the treatment and outcomes of patients with acute coronary syndromes. Am. Heart.J. 163(1): 66-73.

Prescott, E., Hippe, M., Schnohr, P., Hein, H.O. \& Vestbo, J. 1998. Smoking and risk of myocardial infarction in women and men: Longitudinal population study. BMJ 316(7137): 1043-1047.

Radovanovic, D., Erne, P., Urban, P., Bertel, O., Rickli, H., Gaspoz, J.M. \& Investigators, A.P. 2007. Gender differences in management and outcomes in patients with acute coronary syndromes: Results on 20,290 patients from the amis plus registry. Heart 93(11): 1369-1375.

Ray, K.K., Cannon, C.P., Cairns, R., Morrow, D.A., Ridker, P.M \& Braunwald, E. 2009. Prognostic utility of apob/ai, total cholesterol/hdl, non-hdl cholesterol, or hs-crp as predictors of clinical risk in patients receiving statin therapy after acute coronary syndromes: Results from prove it-timi 22 . Arterioscler. Thromb. Vasc. Biol. 29(3): 424-430.

Reibis, R., Treszl, A., Wegscheider, K., Bestehorn, K., Karmann, B. \& Voller, H. 2012. Disparity in risk factor pattern in premature versus late-onset coronary artery disease: A survey of 15,381 patients. Vasc. Health Risk Manag. 8: 473-481.

Ripatti, S., Tikkanen, E., Orho-Melander, M., Havulinna, A.S., Silander, K., Sharma, A., Guiducci, C., Perola, M., Jula, A., Sinisalo, J., Lokki, M.L., Nieminen, M.S., Melander, O., Salomaa, V., Peltonen, L. \& Kathiresan, S. 2010. A multilocus genetic risk score for coronary heart disease: Case-control and prospective cohort analyses. Lancet 376(9750): 1393-1400.

Ross, R. 1993. The pathogenesis of atherosclerosis: A perspective for the 1990s. Nature 362(6423): 801-809.

Ruiz-Garcia, J., Lerman, A., Weisz, G., Maehara, A., Mintz, G.S., Fahy, M., Xu, K., Lansky, A.J., Cristea, E., Farah, T.G., Teles, R., Botker, H.E., Templin, B., Zhang, Z., De Bruyne, B., Serruys, P.W. \& Stone, G.W. 2012. Age- and genderrelated changes in plaque composition in patients with acute coronary syndrome: The prospect study. EuroIntervention 8(8): 929-938.

Sadeghian, S., Fallahi, F., Salarifar, M., Davoodi, G., Mahmoodian, M., Fallah, N., Darvish, S., Karimi, A. \& Tehran Heart, C. 2006. Homocysteine, vitamin b12 and folate levels in premature coronary artery disease. BMC Cardiovasc Disord 6: 38. https://doi.org/10.1186/1471-2261-6-38. 
Saito, H., Lund-Katz, S. \& Phillips, M.C. 2004. Contributions of domain structure and lipid interaction to the functionality of exchangeable human apolipoproteins. Prog. Lipid Res. 43(4): 350-380.

Satoh, H., Nishino, T., Tomita, K., Saijo, Y., Kishi, R. \& Tsutsui, H. 2006. Risk factors and the incidence of coronary artery disease in young middle-aged Japanese men: Results from a 10-year cohort study. Intern. Med. 45(5): 235-239.

Satti, H.S., Hussain, S. \& Javed, Q. 2013. Association of interleukin-6 gene promoter polymorphism with coronary artery disease in Pakistani families. Scientific World Journal 2013: 538365.

Sekuri, C., Cam, F.S., Sagcan, A., Ercan, E., Tengiz, I., Alioglu, E. \& Berdeli, A. 2007. No association of interleukin-6 gene polymorphism $(-174 \mathrm{~g} / \mathrm{c})$ with premature coronary artery disease in a turkish cohort. Coron. Artery Dis. 18(5): 333-337.

Sesso, H.D., Lee, I.M., Gaziano, J.M., Rexrode, K.M., Glynn, R.J. \& Buring, J.E. 2001. Maternal and paternal history of myocardial infarction and risk of cardiovascular disease in men and women. Circulation 104(4): 393-398.

Shabbir, S., Khan, D.A., Khan, F.A., Elahi, M.M. \& Matata, B.M. 2011. Serum gamma glutamyl transferase: A novel biomarker for screening of premature coronary artery disease. Cardiovasc. Revasc. Med. 12(6): 367-374.

Shehab, A., Al-Dabbagh, B., Alhabib, K.F., Alsheikh-Ali, A.A., Almahmeed, W., Sulaiman, K., Al-Motarreb, A., Nagelkerke, N., Al Suwaidi, J., Hersi, A., Al Faleh, H., Asaad, N., Al Saif, S. \& Amin, H. 2013. Gender disparities in the presentation, management and outcomes of acute coronary syndrome patients: Data from the 2nd gulf registry of acute coronary events (gulf race-2). PLoS One 8(2): e55508.

Shojaie, M., Pourahmad, M., Eshraghian, A., Izadi, H.R. \& Naghshvar, F. 2009. Fibrinogen as a risk factor for premature myocardial infarction in iranian patients: A case control study. Vasc. Health Risk Manag. 5: 673-676.

Siegerink, B., Maas, R., Vossen, C.Y., Schwedhelm, E., Koenig, W., Boger, R., Rothenbacher, D., Brenner, H. \& Breitling, L.P. 2013. Asymmetric and symmetric dimethylarginine and risk of secondary cardiovascular disease events and mortality in patients with stable coronary heart disease: The karola follow-up study. Clin. Res. Cardiol. 102(3): 193-202.

Siemelink, M.A. \& Zeller, T. 2014. Biomarkers of coronary artery disease: The promise of the transcriptome. Curr. Cardiol. Rep. 16(8): 513.

Sondermeijer, B.M., Bakker, A., Halliani, A., De Ronde, M.W., Marquart, A.A., Tijsen, A.J., Mulders, T.A., Kok, M.G., Battjes, S., Maiwald, S., Sivapalaratnam, S., Trip, M.D., Moerland, P.D., Meijers, J.C., Creemers, E.E. \& PintoSietsma, S.J. 2011. Platelets in patients with premature coronary artery disease exhibit upregulation of mirna340* and mirna624*. PLoS One 6(10): e25946.

St-Pierre, A.C., Cantin, B., Dagenais, G.R., Mauriege, P., Bernard, P.M., Despres, J.P. \& Lamarche, B. 2005. Lowdensity lipoprotein subfractions and the long-term risk of ischemic heart disease in men: 13-year follow-up data from the quebec cardiovascular study. Arterioscler. Thromb. Vasc. Biol. 25(3): 553-559.

Sun, X., Zhang, M., Sanagawa, A., Mori, C., Ito, S., Iwaki, S., Satoh, H. \& Fujii, S. 2012. Circulating microRNA-126 in patients with coronary artery disease: Correlation with LDL cholesterol. Thrombosis Journal 10(1): 16.

Taraboanta, C., Hague, C.J., Mancini, G.B., Forster, B.B. \& Frohlich, J. 2012. Coronary artery calcium findings in asymptomatic subjects with family history of premature coronary artery disease. BMC Cardiovasc. Disord. 12: 53.

Tatli, E., Ozcelik, F. \& Aktoz, M. 2009. Plasma fibrinogen level may predict critical coronary artery stenosis in young adults with myocardial infarction. Cardiol. J. 16(4): 317-320.

Tolstrup, J.S., Hvidtfeldt, U.A., Flachs, E.M., Spiegelman, D., Heitmann, B.L., Balter, K., Goldbourt, U., Hallmans, G., Knekt, P., Liu, S., Pereira, M., Stevens, J., Virtamo, J. \& Feskanich, D. 2014. Smoking and risk of coronary heart disease in younger, middle-aged, and older adults. Am. J. Public Health 104(1): 96-102.

Uddin, S.N., Siddiqui, N.I., Bagum, F., Malik, F., Rahman, S. \& Ali, M.S. 2004. Coronary artery disease in young adults - angiographic profile. Mymensingh Med.J. 13(1): 11-15.

Wan Ahmad, W.A. \& Sim, K.H. 2013. Annual Report of the NCVD-ACS Registry, 2009 \& 2010. National Cardiovascular Disease Database, Kuala Lumpur, Malaysia.

Wang, F., Long, G., Zhao, C., Li, H., Chaugai, S., Wang, Y., Chen, C. \& Wang, D.W. 2013. Plasma microRNA-133a is a new marker for both acute myocardial infarction and underlying coronary artery stenosis. Journal of Translational Medicine 11: 222 .

Watkins, H. \& Farrall, M. 2006. Genetic susceptibility to coronary artery disease: From promise to progress. Nat. Rev. Genet. 7(3): 163-173.

Weber, M., Baker, M.B., Patel, R.S., Quyyumi, A.A., Bao, G. \& Searles, C.D. 2011. Microrna expression profile in cad patients and the impact of acei/arb. Cardiol. Res. Pract. 2011: 532915.

Weber, M., Mcnicoll, S., Marcil, M., Connelly, P., Lussier-Cacan, S., Davignon, J., Latour, Y. \& Genest, J. Jr. 1997. Metabolic factors clustering, lipoprotein cholesterol, apolipoprotein b, lipoprotein (a) and apolipoprotein e phenotypes in premature coronary artery disease in french canadians. Can.J. Cardiol. 13(3): 253-260

Wilkins, J.T., Gidding, S., Liu, K., Ning, H., Polak, J.F. \& LloydJones, D.M. 2014. Associations between a parental history of premature cardiovascular disease and coronary artery calcium and carotid intima-media thickness: The coronary artery risk development in young adults (cardia) study. Eur. J. Prev. Cardiol. 21(5): 601-607.

Wilson, P.W., D'agostino, R.B., Levy, D., Belanger, A.M., Silbershatz, H. \& Kannel, W.B. 1998. Prediction of coronary heart disease using risk factor categories. Circulation 97(18): 1837-1847.

Yancey, P.G., Bortnick, A.E., Kellner-Weibel, G., De La Llera-Moya, M., Phillips, M.C. \& Rothblat, G.H. 2003. Importance of different pathways of cellular cholesterol efflux. Arterioscler. Thromb. Vasc. Biol. 23(5): 712-719.

Yayan, J. 2013. Emerging families of biomarkers for coronary artery disease: Inflammatory mediators. Vasc. Health Risk Manag. 9: 435-456.

Yunus, A.M., Sherina, M., Nor Afiah, M., Rampal, L. \& Tiew, K. 2004. Prevalence of cardiovascular risk factors in a rural community in mukim Dengkil, Selangor. Malays. J. Nutr. 10(1): 5-11

Zhu, C., Xiong, Z., Zheng, Z., Chen, Y., Qian, X. \& Chen, X. 2013. Association of serum gamma-glutamyltransferase with arterial stiffness in established coronary artery disease. Angiology 64(1): 15-20.

Zieske, A.W., Mcmahan, C.A., Mcgill, H.C., Jr., Homma, S., Takei, H., Malcom, G.T., Tracy, R.E. \& Strong, J.P. 2005. 
Smoking is associated with advanced coronary atherosclerosis in youth. Atherosclerosis 180(1): 87-92.

Zieske, A.W., Takei, H., Fallon, K.B. \& Strong, J.P. 1999.

Smoking and atherosclerosis in youth. Atherosclerosis 144(2): 403-408.

Muhammad Faizan A. Shukor*, Noor Akmal Shareela Ismail \& Wan Zurinah Wan Ngah

Department of Biochemistry

Faculty of Medicine, UKM Medical Centre

Universiti Kebangsaan Malaysia

Jalan Ya'acob Latif, Bandar Tun Razak

50300 Kuala Lumpur, Federal Territory

Malaysia
Muhammad Faizan A. Shukor*

Centre for Chemical Defense

Universiti Pertahanan Nasional Malaysia (UPNM)

Kem Sungai Besi

57000 Kuala Lumpur, Federal Territory

Malaysia

*Corresponding author; email: mfaizanshukor@gmail.com

Received: 21 May 2018

Accepted: 25 June 2018 